\title{
Reindeer Ranching in Canada ${ }^{1}$
}

\section{GEORGE W. SCOTTER}

\author{
Research Scientist, Canadian Wildlife Service, \\ Departmenl of the Environment, Edmonton, Alberta.
}

\section{Highlight}

Of five attempts to develop reindeer ranching in Canada, the Mackenzie Delta herd is the only one still in operation. That herd was established to supplement the region's wildlife resources and to improve the Eskimos' economic condition by creating a number of viable native-owned herds. All of the nativeowned herds, established from the nucleus herd, eventually reverted to government ownership. The reindeer operation has not proven to be economically viable. Game ranching with native animals in northern Canada may offer the best potential for conversion of vegetation into meat.

Reindeer husbandry, one of the oldest known means of livelihood in the arctic and subarctic regions of Eurasia, can be traced back to the ninth century, when the Lapps began herding reindeer (Skuncke, 1969). Reindeer husbandry was confined to Eurasia until the late 1800 's.

Between 1891 and 1902, 1,280 reindeer (Rangifer tarandus) were imported into Alaska from Siberia. They were introduced by Dr. Sheldon Jackson, first superintendent of education in Alaska, to supplement the coastal Eskimos' food supply, derived from sea and land mammals. Reindeer numbers reached 640,000 by 1930 , but were reduced to about 25,000 by 1950 , because of range deterioration, poor herding practices and disputes about ownership (Brady, 1968). An influenza epidemic in 1918 resulted in much confusion about ownership of the reindeer, so community- and association-owned herds were encouraged. Individual herdsmen then became less interested in the reindeer.

At present there are about 40,000 reindeer in Alaska: half of them privately owned, half government owned or in feral herds. State and federal agencies are expending con-

\footnotetext{
${ }^{1}$ Based on papers presented at the 24th Annual Meeting, Society of Range Management, Reno, Nevada, February 17, 1971; and the Conference on Productivity and Conservation in Northern Circumpolar Lands, Edmonton, Alberta, October, 1969.
}

siderable effort to develop an cconomically profitable operation. Lantis (1950), Hanson (1952), De Leonardis (1959), Nygard (1965) and Brady (1968) provide additional history of the reindeer industry in Alaska.

The apparent success of reindeer introductions in Mlaska stimulated interest in similar introductions into Canada.

\section{Labrador Experiment}

Dr. W. T. Grenfell, supported by the Boston Transcript and Canada Department of Agriculture, purchased 300 reindeer in Norway. Thcy werc brought, with three Lapp families to herd them, to Cremélière, near St. Anthony, Newfoundland, in 1908 (Grenfell, 1919). The herd increased to about 1,300 by 1912 , but its Lapp herders, discouraged by the unfavorable climatc and low pay, returned home. Lacking proper care, the herd decreased. But poaching, indifference, and ignorance of the local people also contributed to its decline.

Grenfell was in France during the First World War and upon his return only 230 reindeer could be found. The experiment had failed, but Grenfell remained enthusiastic about establishing a viable reindeer industry in Canada. In 1918, with assistance from the Canadian Government, about 150 of the remaining reindeer were captured and taken to Rocky Bay on the north shore of the St. Lawrence River.
The reindeer were subsequently moved to Anticosti Island, where they were allowed to run wild, but they did not thrive, probably because suitable forage was lacking (Tilton, 1965). The last reindeer reported on the island was seen in 1949 and the animals are believed to be extinct there (Cameron, 1958).

Earlier, in 1911, the Department of the Interior bought 50 head of reindeer from Grenfell. The animals were driven and transported by ship, rail, horse-drawn wagons, and scows from St. Anthony, Newfoundland towards their destination in the Great Slave Lake region of the District of Mackenzie (Hedlin, 1961; Inglis, 1969). Deaths and straying throughout the journey caused a great decline. The herd was reduced by 1916 to a single reindeer which the herder ate; thus ending an experiment costing more than $\$ 60,000$.

\section{Hudson's Bay Reindeer Company}

In May 1919, the Canadian Government appointed a Royal Commission to investigate the possibilities of reindeer and musk-oxen (Ovibos moschatus) herding in the arctic and subarctic regions of Canada. Before the report was completed, V. Stefansson resigned from the commission, applied for and was granted grazing privileges on more than 100,000 square miles of southern Baffin Island. He then persuaded the Hudson's Bay Company to set up a subsidiary, Hudson's Bay Reindeer Company, of which he was a director and technical adviser (Stefansson, 1964). S. T. Storkerson was hired to study the grazing prospects on the leasehold and reported enthusiastically on the vegetation and its suitability for reindeer.

Representatives of the Hudson's Bay Reindeer Company went to Norway to purchase reindeer, and on October 13, 1921 the 'Nascopie' sailed with 627 reindeer and six Lapp herders. Seventy-seven reindeer died before arrival in Amadjuak Bay on November 1. On landing, the reindeer scattered in all 
directions in search of food. The herders rounded up only 260 animals.

The reindeer did not find forage of the quality and in the quantity Storkerson so optimistically reported, for he had evidently mistaken mosses for lichens. The reindeer lichens, so important in winter, were very scarce, and the reindeer had to forage over large areas. By the summer of 1923, only 181 reindeer remained in the herd. In the fall, the last of the Lapp herders returned to Norway. In the winter of 1924-25 most of the herd disappeared. On May 27, 1927 the grazing permit of the Hudson's Bay Reindeer Company was cancelled and the enterprise officially concluded. Begun with high hopes, the Baffin Island experiment ended a total failure, and cost $\$ 200,000$ (Stefansson, 1964).

Officials of the Hudson's Bay Company blamed the lack of feeding grounds; Stefansson blamed inefficient herding and management. The originators of this scheme assumed that good caribou country would make good reindeer range country. They forgot that though the two species eat the same kinds of forage, one can roam free in search of food while the other, if it is to be of any use to its owners, must be kept on a limited range, rich enough to allow herding. Even the best management of reindeer on Baffin Island where the animals were set ashore would probably not have forestalled failure of the herd, because forage was too sparse to support the herd in a limited area.

\section{Mackenzie Delta Experiment}

The Royal Commission report (Rutherford et al., 1922) recommended that small experimental reindeer herds be established in several places. Thus in April, 1926, A. E. Porsild, assisted by his brother, was appointed to make a general botanical reconnaissance of northwestern Canada with special reference to reindeer pasture and other general conditions which would be important to future reindeer hus-

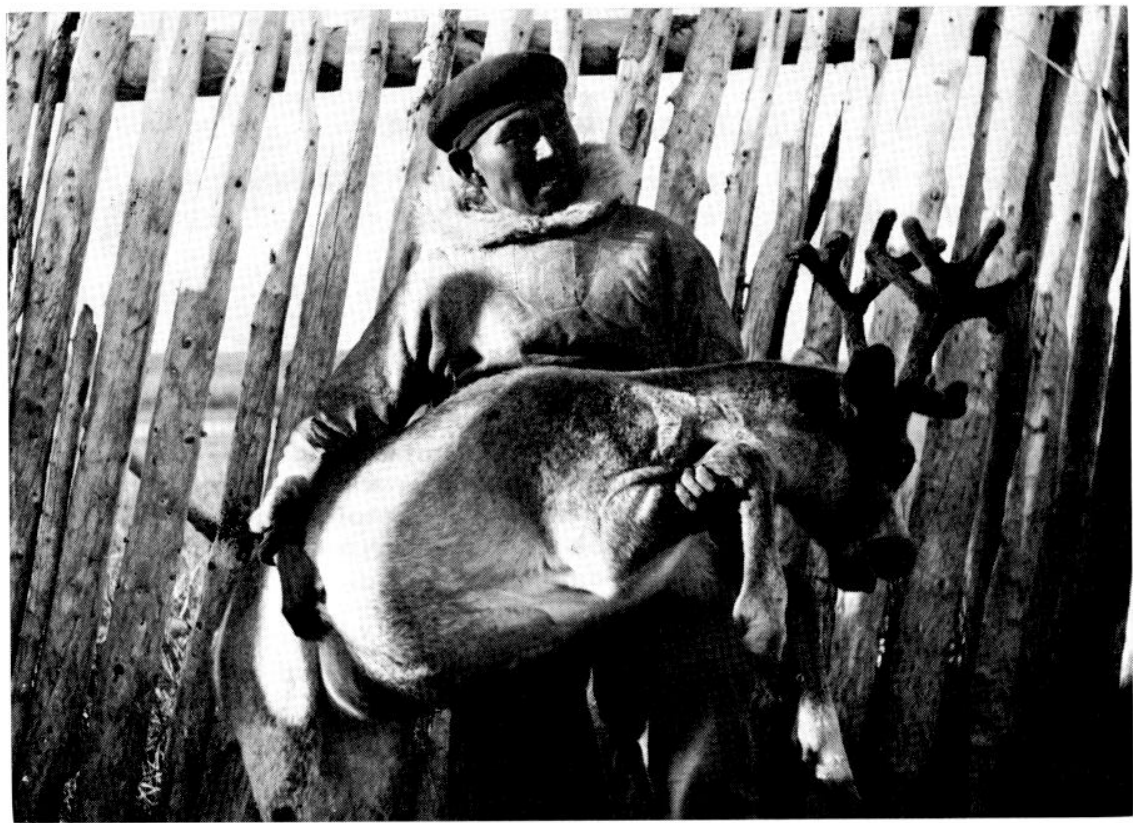

Fig. 1. The original purpose of the reindeer venture in the Mackenzie Delta was to improve the economic condition of the native people by supplementing the wildlife resources of the region. (Photo Department of Indian Affairs and Northern Development.)

bandry. Porsild (1929) concluded that the arctic coast and Eskimo Lakes regions of the District of Mackenzie had a carrying capacity for at least 250,000 reindeer while the Great Bear Lake basin could support 300,000 more.

In 1929 the Canadian government and the Lomen Reindeer Company of Alaska agreed on the delivery of 3,000 reindeer to the Mackenzie River delta. The delivery was completed in 1935, after a drive which took six winters and five summers (Miller, 1935; Lomen, 1954; Scotter, 1966). The final tally was 2,382 reindeer, comprising 1,498 does, 611 bucks, and 273 steers. Only 10 percent of the animals were from the original herd; 90 percent had been born on the trail. This was fewer than the 3,000 animals agreed on, but the birth of 800 fawns within a few weeks more than made up for the short delivery.

This reindeer venture was intended to improve the economic plight of the native people by supplementing the herds of barrenground caribou (Rangifer tarandus groenlandicus) and other wild mammals which had dwindled, as they had elsewhere, after traders arrived in the Arctic and firearms were introduced (Fig. 1). Wild mammals had been the principal livelihood of the Eskimos. Shortage of game forced them to resort to trapping so they could obtain money to buy food and other necessities. The Eskimos' economic condition, therefore, varied with the fluctuating supply of fur-bearing animals and the price of pelts.

\section{The Reindeer Preserve}

\section{Location}

The Reindeer Preserve, near Inuvik, Northwest Territories, is bounded by the Beaufort Sea on the north, the Mackenzie River on the west, and the Anderson River on the east. The preserve was 6,600 square miles when it was established in 1933. It was enlarged to 18,000 square miles in 1952. Suggested areas for summer, winter, and spring-fall grazing are show in Figure 2.

Vegetation.-Mackay (1963) described, in detail, the major geographic regions of the preserve. 


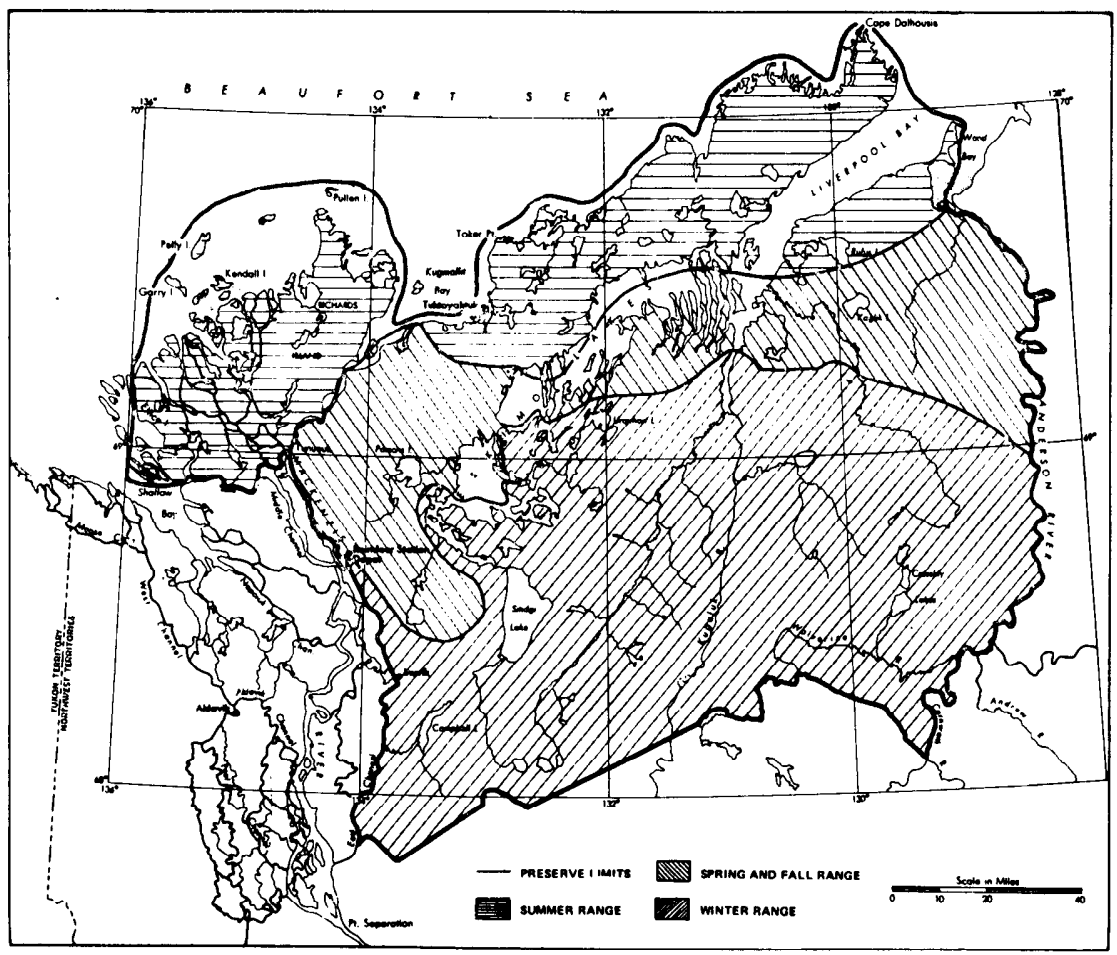

Fic. 2. Map of the Reindeer Preserve showing the suggested areas for summer, winter and spring-fall grazing.

The northern portion of the Reindeer Preserve, including Richards Island, the Plcistocene Coastlands, the northern portion of the Fluted Plains, and the northern part of the Anderson River Uplands, lies within the tundra zone. The southern portion is in the boreal forest zone (Fig. 3). The general vegetation sequence from north to south is ". . . tundra; tundra with scrub willow and ground birch; scrub willow and ground birch; woodland and tundra with much scrub willow and ground birch; open woodland; and continuous woodland ...." (Mackay, 1963).

In the poorly drained tundra area, several communities and microcommunities occur in close association. They may be only a few square feet in size, but they are scattered over large areas. Tundra polygons, mounds, hummocks, ponds and lakes occur frequently. Tussock communities are dominated by sheathed cotton-grass (Eriophorum vaginatum), with dwarf shrubs and sedges occurring in varying degrees of abundance. The composition of stands varies con- siderably. Polygons support a dense carpet of lichens, including Cetraria nivalis, C. cucullata, and Cladonia spp. Sphagnum spp. and other bryophytes cover the depressions between polygons. Mournful sedge (Carex lugens) is the most common of several sedge species occurring in many communities on the tundra. R. F. Nowosad.)
Salt-marsh sedges (Carex salina and C. subspathacea) occur in dense mats along seashores subject to flooding at high tidc.

The better drained parts of the tundra support dryas (Dryas integrifolia), white heather (Cassiope tetragona), willows (Salix arctica and $S$. glauca), and grasses (Poa spp., Trisetum spicatum and Arctagrostis latifolia).

Open woodlands comprise most of the area east of the InuvikCampbell Lake region; continuous woodlands, as mapped by Mackay (1963), occur in the southwesterly fringe of the preserve. White spruce (Picea glauca) and black spruce $(P$. mariana) predominate most upland sites. Black spruce dominates muskeg terrain, also. Paper birch (Betula resinifera), larch (Larix laricina), and balsam poplar ( $P o p u$ lus balsamifera) are dispersed on favorable sites. Several lichens, in association with sedges, grasses, and various ericaceous shrubs, comprise much of the cover among the trees. These lichens, especially Cladonia alpestris, C. arbuscula, C. mitis, and $C$. rangiferina, are a major winter forage for reindeer (Fig. 4).

Willows (Salix spp.), ground birch (Betula glandulosa), alder (Alnus crispa) and ericaceous shrubs are characteristic shrubs occurring in

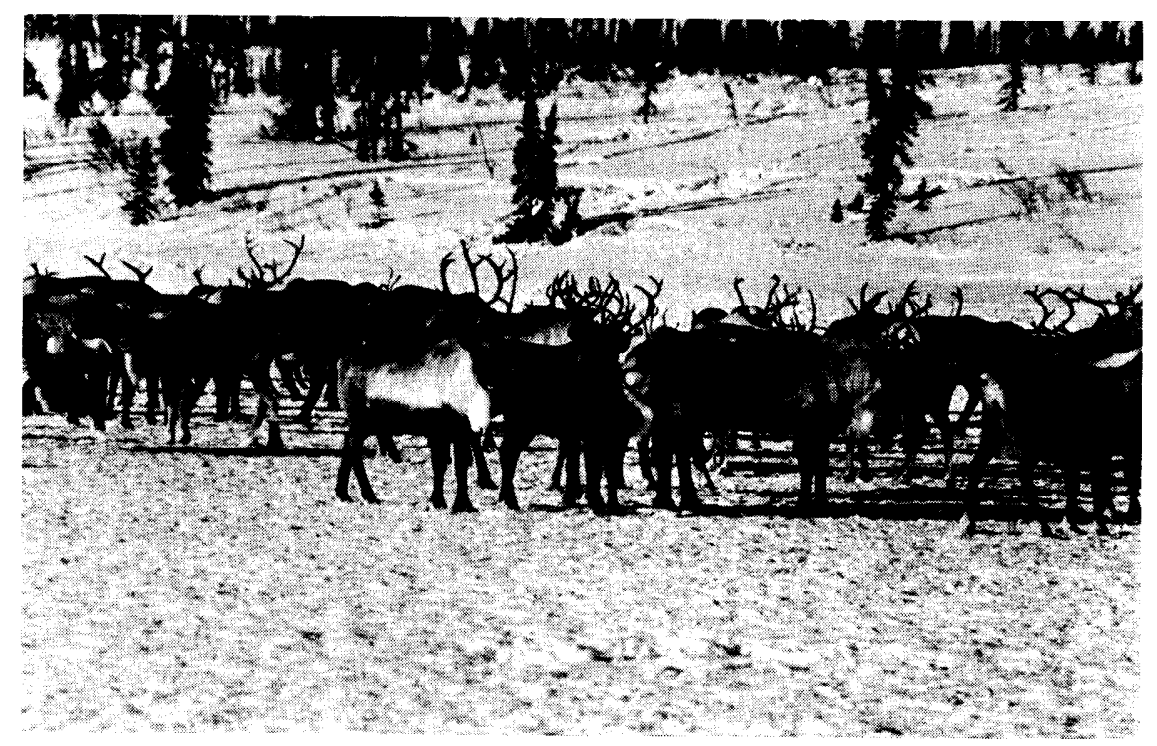

Fic. 3. A reindeer herd on the winter range within the taiga forest zone. (Photo by 


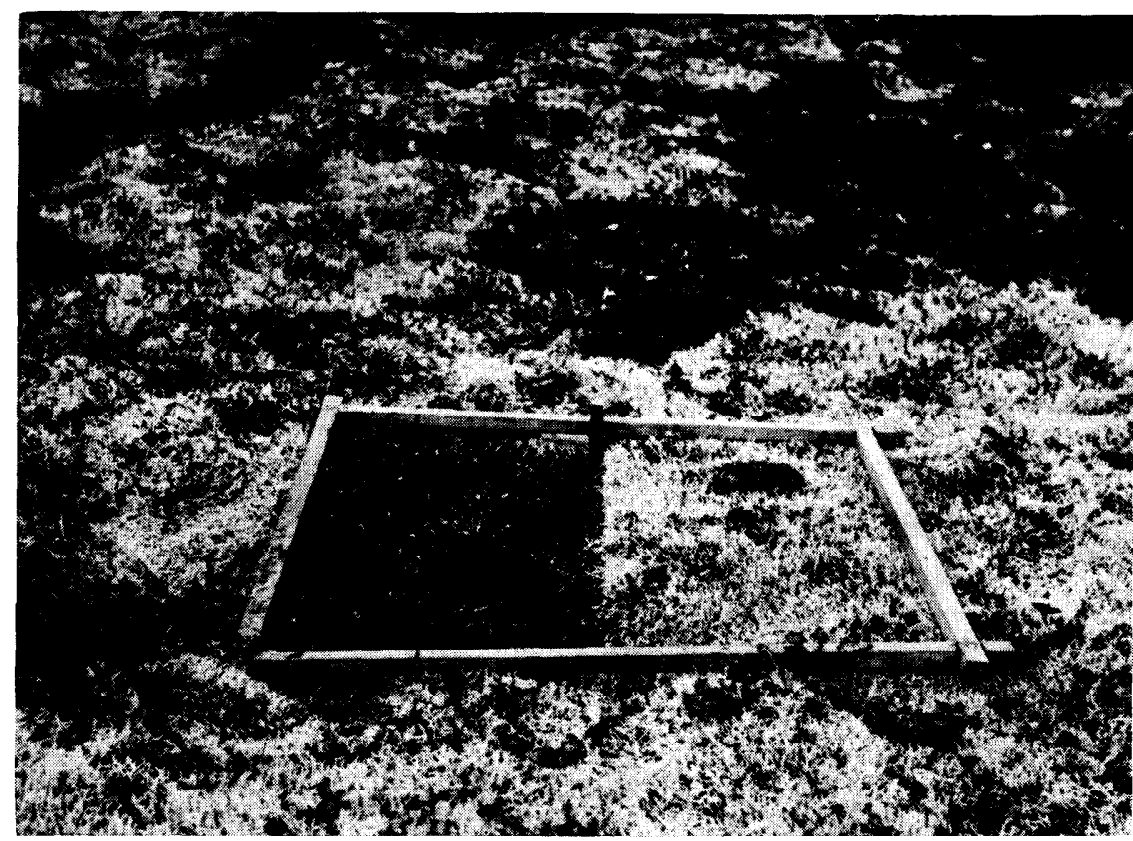

Fig. 4. Lichens, particularly Cladonia spp., are an important item in the winter diet of reindeer. Although the carbohydrate content of most lichens used as forage is high, the protein content is low as shown. (Photo by G. W. Scotter)

the transitional zone between tree line and tundra. Several sedges, grasses, and lichens thrive in association with the shrubs. Fires have burnt part of the open woodland and shrub communities, especially between the Caribou Hills and Kugaluk River.

Climate.-The coastal area of the Reindeer Preserve lies in the arctic zone, the southern portion in the subarctic (Mackay, 1963). The mean annual total precipitation is low, ranging from 6 inches at Tuktoyaktuk to 11 inches at Inuvik. Fog is common in summer, especially along the coast. Mean temperatures in July and August are only about $50 \mathrm{~F}$. Winters are long and cold with snowfall increasing inland from the coast.

\section{Carrying capacity}

Without the benefit of maps or aerial photographs, Porsild (1929), estimated the Arctic Coast in northwestern Canada would support 250,000 reindeer. The Reindeer Preserve now takes up about onethird of that area, so, based on Porsild's estimate, it should support approximately 85,000 reindeer
(Hill, 1967). Porsild (1936) estimated the original preserve of 6,600 square miles would indefinitely support 25,000 reindeer, Clarke (1942) estimated 50,000 animals.

The preserve was tripled in 1952 to 18,000 square miles. $S$. B. Johansson, a former herd manager, estimated in 1965 it would carry 30,000 reindeer. Scotter (1968) studied range conditions and trends in 1965 and 1966 and agreed with Johansson's estimate, provided good range management practices were employed and all 18,000 square miles utilized. Only about one-quarter of the preserve has been under intensive use.

Estimates of carrying capacity have been too high, partly because the time required by lichens for recovery from grazing was not considered. In Sweden, Skuncke (1969) concluded that reindeer need 8 to 10 times more range than was previously calculated.

Fires have burned over many square miles of open woodland and scrub vegetation between the Caribou Hills and Kugaluk River. If the preserve's carrying capacity is to be maintained, fires on the winter range must be controlled. One major fire could destroy the basis of the whole reindeer operation. The area is becoming more accessible to fishermen and tourists, and the risk of fire is increasing.

Oil exploration on the preserve has expanded rapidly and its effects on carrying capacity and movement of reindeer can only be conjectured. If the best practices are cmployed, the effects should be minimal and temporary.

\section{Management of the Herds}

The original plan of the reindeer experiment was to set up a government-owned main herd from which smaller herds would be formed, as numbers permitted. The smaller herds would be turned over to suitable Eskimo herdsmen, each assigned to particular winter and summer ranges. As these herds increased, their holders would repay the number of animals they had been given. The herds would eventually become self-supporting units. These objectives were never reached.

Between 1938 and 1954, six Eskimo-owned herds of about 1,000 animals each were established. Most of these herds increased in numbers for a few years, declined, and finally reverted to government ownership. The owners of the two herds first formed were killed in a boating accident in 1944 and their herds were amalgamated under government supervision. The last Eskimoowned herd was returned to the government in 1964.

The reasons for the failure of the reindeer experiment were many and complex. Lantis (1954) suggested that the Eskimos' resisted reindeer herding because few could be enthusiastic about the monotonous tasks of reindeer herding. To change a hunter into a herder would mean changing not only his life style but also his whole psychology. Most Eskimos were unwilling to turn from hunting and trapping and a settled community life to become mere followers of reindeer. In the late 1950 's, more 
rewarding employment, such as wage labor and more remunerative trapping, became available. These were seasonal and did not have to be carried on throughout the year to be profitable.

Sonnenfeld (1959) suggested that the inland Eurasian herders, who originally hunted wild reindeer, could make the transition to herding domesticated reindeer becausc they were accustomed to following animals. He speculated that reindeer ranching might have been more successful among inland Eskimos in Alaska than among the coastal Eskimos who lived in permanent settlements for a good part of the year. The same theory could perhaps be applied to the Eskimos of the Mackenzie Delta.

Predation, poaching, and disease, such as footrot and an undetermined wcak-bone ailment that occasionally afflicts the herds, were among other minor problems.

The Mackenzie reindeer operation suffered from attempts to apply 'Lappish' practices. Many animal husbandry and range management techniques employed in Scandinavia are years behind those employed in livestock operations in North America. Some unfavorable practices are close herding, unsatisfactory herd structures with a high ratio of males to females, and poor breeding methods. The assumption that the Laplander's pastoral practices were suited to the Canadian reindeer operation is certainly questionable. The Fennoscandian reindeer operation has itself been plagued with problems (Scotter, 1965), although the adoption of modern practices is improving the outlook for the industry.

The Canadian reindeer operation has lacked effective direction partly because some of its managers have not had experience with livestock or wildlife management, partly because a coherent, practical policy was not set; partly because of a lack of biological data. The lack of funds and the great distance to the decision making body in Ottawa were also major problems.

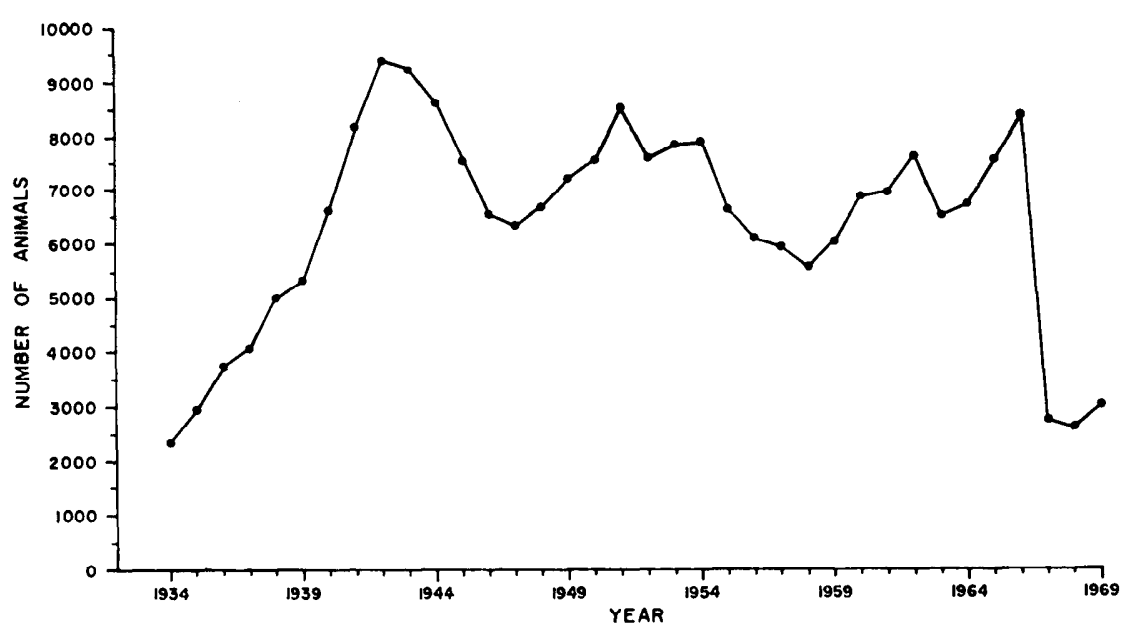

FIG. 5. Estimated total number of reindeer in all herds at the Reindeer Preserve at the end of the year, 1935 to 1968 [data taken from Krebs (1961), Hill (1967), and the files at the Reindeer Station].

From 1960 to 1968 the reindeer project was in the hands of a private contractor who, it was hoped, would put it on a self-supporting footing. But costs exceeded revenues by a ratio of 3 to 1 , during the entire period.

Often herding was casual from 1963 until 1968, with the animals occasionally observed from the air, when the contract was terminated. During that time, the reindeer population decreased from 8,400 to about 2,800 animals. Preobrazhenskii (1968) suggested that free and semi-free grazing should not be used in Russia, but Mäki (1966) noted that intensive reindeer husbandry is giving way to more extensive methods in Finland. Casual herding with only sporadic supervision was discredited by the results obtained in Canada.

The Canadian Wildlife Service assumed responsibility for operations in April 1968. It proposes to make scientific studies of the animals and their ranges, and to develop management techniques that will ensure a high yield of meat at reasonable cost. The eventual goal of the Department of Indian Affairs and Northern Development is private ownership, preferably by native people. As in the past, the project will be heavily subsidized for the next few years. However, with added biological management and research the feasibility of continuing the operation as a viable economic industry will be tested.

\section{Growth and Decline of the Herds}

Numbers increased from 2,382 when the reindeer were delivered in 1935 to 9,347 in 1942 . The totals have since fluctuated between 5,000 and 9,000 (Fig. 5). The population was estimated at 2,800 from aerial counts in 1967.

Between 1935 and 1969 some 65,000 reindeer fawns were born on the preserve. Annual fawn crops have ranged from 815 , born after the herd's arrival in 1935, to an estimated 3,700 in 1966 (Fig. 6). Some estimates in recent years, like the one in 1966, are questionable, since the fall herd count in 1967 was under 2,800. The proportion of fawns in the herd has ranged from 24 to 35 percent.

From 1935 to 1969 , about 29,000 reindeer were slaughtered, ranging from none in 1935 to 1,786 in 1955 (Fig. 6). Natural losses, including straying, have accounted for 30,000 animals, ranging from 70 in 1940 to 2,738 in 1945 to 5,600 in 1967 . Excluding the apparent large loss in 1967 which may be due to errors in population estimates made while the reindeer were managed under contract, losses have been as high as 36 percent of the herd in one year. Krebs (1961) and Hill (1967) 


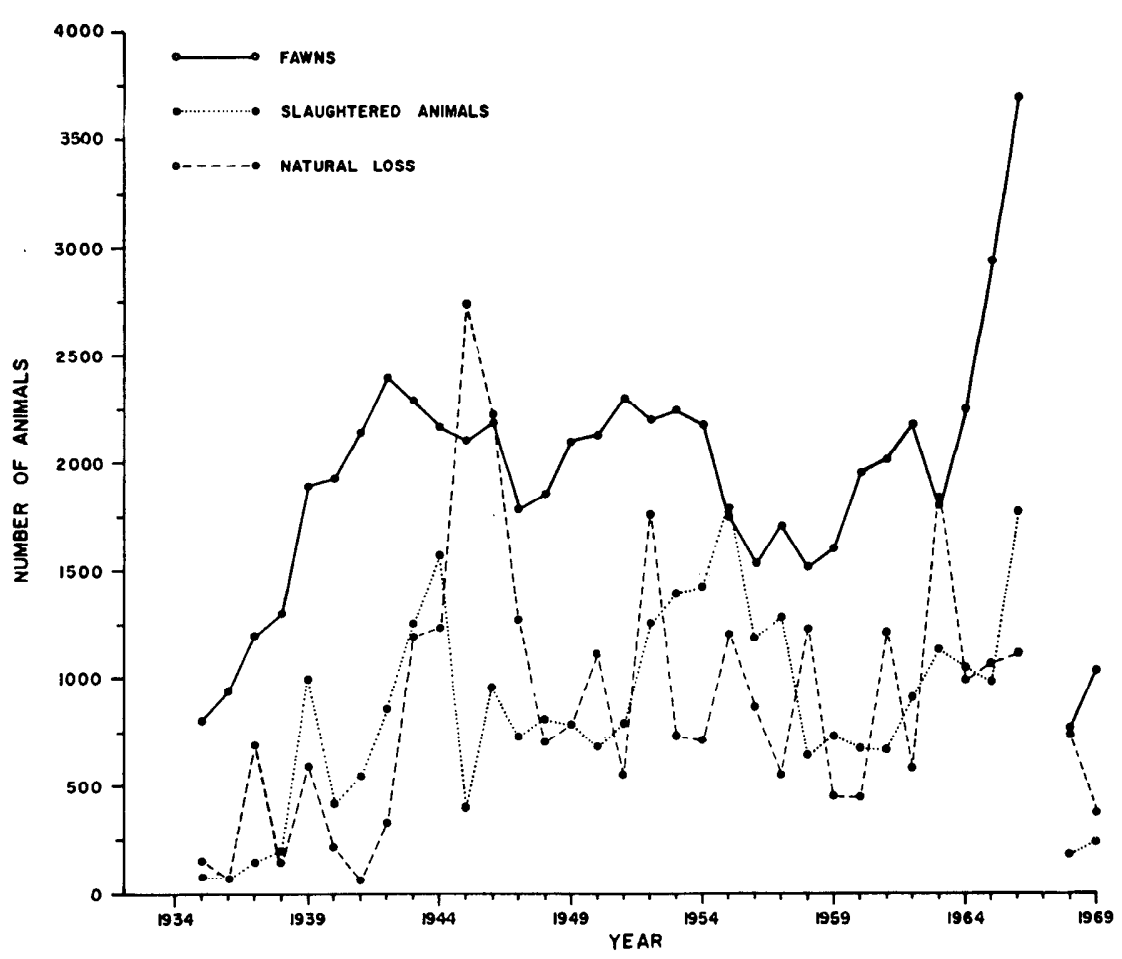

FiG. 6. Estimated number of fawns, slaughtered animals, and natural losses at the Reindeer Preserve, 1935 to 1969 [data taken from Krebs (1961), Hill (1967), and the files at the Reindeer Station].

give more details on the population dynamics of the herd.

\section{Future of the Herd}

The possibility that reindeer herding will become a viable industry in the Mackenzie Delta region cannot be totally dismissed. Hill (1967) estimated the potential local market for reindeer meat was 150,000 pounds in 1967 , increasing to 210,000 to 280,000 pounds by 1977. He calculated that a herd maintained at 30,000 reindeer could produce a sustained yield of over $1,000,000$ pounds per year. Certain economies in operation could be expected as the size of the reindeer operation increased. The availability of fresh, moderately priced reindeer meat has undoubtedly contributed to the economy of the delta. In addition, the industry has provided employment for local people.

The economic feasibility of the reindeer project can be assessed only after we know more about the yield of the herd under improved techniques, the possible impact of exist in the interior mainland area ... constitute a valuable national asset, the importance of which, if properly dealt with, can be enormously enhanced. . . ." In recent years, the Cianadian reindeer industry has been little more than a game management operation.

The fact that an exotic species is replacing a native one on the preserve has caused insufficient concern among biologists and ecologists. Hall (1963) wrote, "Introducing an cxotic species is a destructive action resulting from the ignorance of well-meaning persons. . . . Introducing exotic species of vertebrates is unscientific, economically wasteful, politically short-sighted, and biologically wrong." The same statement should perhaps be applied to reindeer on the preserve.

Game-ranching caribou could provide natives with an activity more in line with their traditional pursuits. It could supply local areas with fresh meat at competitive prices and by-products, such as skins and hoofs, that could be used for handicrafts. Caribou has been an unreliable food source in northern areas because of large fluctuations in numbers. Research and modern game management may prevent this. Kelsall (1968) stated that the caribou herd north of Great Bear Lake, which includes those animals infringing on the Reindeer Preserve, have been consistently underutilized. He suggested that proper management could increase the harvest so that export might be allowed. Pearson (1971) suggested that harvesting and marketing caribou from the Porcupine herd, a large international herd distributed in northern Alaska, Yukon Territory and the northwestern fringe of the District of Mackenzie, might be considered. We should give priority to gaining sufficient knowledge of caribou in the northwestern District of Mackenzie and the northern Yukon to support sound management recommendations.

Discontinuing the reindeer project may not be politically feasible, as it would give rise to strong local 
protest but, in the long term, gameranching with caribou may be ecologically and economically more feasible.

\section{Native Animals Versus Reindeer in Other Areas of Northern Canada}

In other areas of northern Can. ada, caribou and other native animals, such as moose (Alces alces) and musk-oxen, may offer the best potential for converting northern vegetation into commodities for consumption by man. Such animals provide meat, hides, hoofs and other products useful to the indigenous and other residents of the North, without the constant attention, skills, and expense required to raisc domesticated animals. If wildlife attractions are properly promoted, non-resident sport hunters and other tourists may well put enough cash into the economy, through the purchase of licenses, hiring of guides, accommodation, and meals, to more than compensate for the lack of revenue from a reindeer industry.

In Africa and other countries native ruminants generally use native forage more cfficicntly than do introduced animals. Klein (1970) believed that the wild populations of caribou and musk-oxen offer the best potential for conversion of vegetation into a usable product in northern Alaska.

\section{Conclusions and Summary}

Reindeer husbandry was introduced into Canada with great expectations but its history has been rather inauspicious. Reindeer were first introduced into Labrador under the direction of Dr. Grenfell, but an initial increase in animal numbers was followed by failure. 'Iransplants from that herd to Anticosti Island and to the Great Slave Lake region were both unsuccessful.

Introduction of reindeer to Baffin Island, by the Hudson's Bay Reindeer Company, was an almost immediate and dramatic failure. Lack of forage and inefficient herding and management wore blamed.
The most successful attempt at rcindeer husbandry in Canada has been in the Mackenzie Delta where a herd was established to supplement wildlife resources by creating a number of viable native-owned herds.

A reindeer industry is biologically feasible, as proven by the maintenance of the reindeer herds there for 35 years, but it has been a social and economic failure for several reasons. Few Eskimos were interested in the monotony of reindeer herding-by 1964 all the native-owned units had ceased operations. Too little consideration was given to modern animal husbandry and range management practices. And, as if that were not enough, some managers were inexperienced, funds were limited and the decisionmaking agency was thousands of miles away in Ottawa. Within the last decade, the reindeer were managed under contract almost as a game-ranching operation but the number of animals declined markedly, presumably because of straying, until 1968 when the Canadian Wildlife Service took over management.

The reindeer in the Mackenzie Delta region are using forage that caribou might otherwise use. Caribou numbers are increasing in the area, and maintaining a reindeer herd is less justified now than when the animals were first introduced here. Whether an introduced species should be allowed to replace a native animal is questionable. The cost of operating the reindeer industry may not be worth the actual or potential benefits since caribou may provide the same products at lower cost.

Native animals in other areas of northern Canada may offer the best potential for converting vegetation into usable products. Under free-ranging conditions, they select the highest quality forage available to them to meet their nutritive requirements. By comparison, reindeer are at a marked disadvantage because they must be confined to be of greatest value to their owners.

\section{Literature Cited}

BRADY, J. 1968. The reindeer industry in Alaska. Alaska Rev. Business Econ. Conditions 5:1-20.

Cameron, A. W. 1958. Mammals of the islands in the Gulf of St. Lawrence. Natl. Mus. Can. Bull. 154. $165 \mathrm{p}$.

Clarke, C. H. D. 1942. Report on development of reindeer industryMackenzie District. Unpubl. rept. in files of the Dep. of Indian Affairs and Northern Development, Ottawa. $17 \mathrm{p}$.

Deleonardis, S. 1959. The reindeer industry in Alaska. Pap. presented at the 9th Alaskan Sci. Conf. 5 p.

Grenfell, W. T. 1919. Forty years for Labrador. Houghton Mifflin Co., Boston and New York. 372 p.

HaLL, E. R. 1963. Introduction of exotic species of mammals. Proc. XVI Int. Congr. Zool. 1:267.

Hanson, H. C. 1952. Importance and development of the reindeer industry in Alaska. J. Range Manage. 5:243251.

Hrduin, R. 1961. Reindeer for the North. The Beaver 291:48-54.

HILl, R. M. 1967. Mackenzie reindeer operations. Northern Coord. and Res. Centre, Dep. Indian Affairs and Northern Development, NCRC 67-1, Ottawa. $161 \mathrm{p}$.

INGLIS, G. 1969. 'And then there were none. . .' North 16(2):6-11.

Kelsall, J. P. 1968. The migratory barren-ground caribou of Canada. Can. Widl. Serv. Monogr. No. 3, Queen's Printer, Ottawa. 310 p.

KLEIN, D. R. 1970. Tundra ranges north of the boreal forest. J. Range Manage. 23:8-14.

Krebs, C. J. 1961. Population dynamics of the Mackenzie Delta reindeer herd, 1938-1958. Arctic 14: 91-100.

Lantis, M. 1950. The reindeer industry in Alaska. Arctic 3:27-44.

Lantis, M. 1954. Problems of human ecology in the North American Arctic. Arctic 7:307-320.

Lomen, C. J. 1954. Fifty years in Alaska. D. McKay Co., New York. $302 \mathrm{p}$.

MACKAY, J. R. 1963. The Mackenzie Delta area, N.W.T. Geogr. Br. Mines and Tech. Surv., Mem. 8. 202 p.

МӓкI, T. V. 1966. Reindeer husbandry as an example of game ranching. Proc. Sixth World Forest. Congr. 3:3688-3693. 
Miller, M. 1935. The great trek. Doubleday, New York. 224 p.

Nygard, E. L. 1965. Reindeer ranching in Alaska. Pap. presented at the 18th Ann. meeting of the Amer. Soc. Range Manage. 8 p.

Pearson, A. M. 1971. Wildlife resource and its conservation in northern Yukon Territory. Univ. British Columbia Law Rev. 6(1):21-35.

Porsild, A. E. 1929. Reindeer grazing in northwest Canada. Can. Dep. Interior. $46 \mathrm{p}$.

Porsild, E. 1936. The reindeer industry and the Canadian Eskimo. Gcogr. J. 88:1-19.
PreobrazhenskiI, B. V. 1968. Management and breeding of reindeer. In Zhigunov, P. S. (Ed.), Reindeer husbandry. Israel Program Sci. Transl., Jerusalem. p. 78-128.

Rutherford, J. G., J. S. McLean, and J. B. Harkin. 1922. Report of the Royal Commission to investigate the possibilities of the reindeer and musk-ox industries in the arctic and sub-arctic regions of Canada. Can. Dep. Interior. $99 \mathrm{p}$.

Scotter, G. W. 1965. Reindeer ranching in Fennoscandia. J. Range Manage. 18:301-305.

Scotter, G. W. 1966. The reindeer journey. North 13(6):4-8.
ScotTer, G. W. 1968. Study of the range resources and management of the Canadian reindeer operation. Unpubl. rep. in files of the Can. Wildl. Serv., Edmonton. 65 p.

Skuncke, F. 1969. Reindeer ecology and management in Sweden. Univ. Alaska Biol. Pap. No. 8. 82 p.

SonNENFELD, J. 1959. An arctic reindeer industry: growth and decline. Geogr. Rev. 49:76-94.

Stefansson, V. 1964. Discovery. McGraw-Hill Book Co., New York. 411 p.

Tilton, F. B. 1965. Letter of July 2, 1965 from Consolidated Paper Cor. poration Limited to the author. 